\title{
Basic Electrochemical Behavior of Ti-7Cu Alloys for Medical Applications
}

\author{
L.C. TSAO* \\ Department of Materials Engineering, National Pingtung University of Science \& Technology \\ 1, Hseuhfu Road, Neipu, 91201 Pingtung, Taiwan
}

\begin{abstract}
The aim of this study was to investigate the effects of two different treatments, as-cast setup and solution heat treatment, on the general electrochemical corrosion resistance of $\mathrm{Ti}-7 \mathrm{Cu}$ alloy samples immersed in a $0.9 \mathrm{wt} \% \mathrm{NaCl}$ solution at $25^{\circ} \mathrm{C}$. The microstructure was examined by scanning electron microscopy and X-ray diffractometry. Corrosion behavior was tested by potentiodynamic polarization curves. Finer $\alpha^{\prime}$ martensite and $\mathrm{Ti}_{2} \mathrm{Cu}$ intermetallic particles were provided by casting and heat treated processes, respectively. The results indicated that only corrosion potential is significantly more noble in the heat treated sample, but other characteristics are only slightly different.
\end{abstract}

PACS: 68.35.bd, 68.37.Hk, 65.40.gk, 81.40.Cd

\section{Introduction}

Titanium ( $\mathrm{Ti}$ ) and its alloys possess the advantages of high specific strength, good osseointegration, superior corrosion resistance, and biocompatibility. Thus, alloys such as commercially pure titanium (CP-Ti) and Ti6Al4V are used for dental implants and dentures. However, CP-Ti alloy is considered to be one of the more problematic, mainly because of its high melting temperature $\left(1670^{\circ} \mathrm{C}\right)$ and high chemical activation energy at high temperature. The alloy Ti6Al4V is the one most commonly used because of its superior physical and mechanical properties in comparison to CP-Ti alloy [1]. However, the harmful elements $\mathrm{V}$ and $\mathrm{Al}$ present in $\mathrm{Ti} 6 \mathrm{Al} 4 \mathrm{~V}$ tend to be released into the human body $[2,3]$. Hence, additional alloying elements need to be added to make this alloy biocompatible and decrease its liquidus temperature.

One of these elements is copper, which not only decreases the melting point of the alloy [4] but also provides adequate biocompatibility $[5]$ and reasonable corrosion resistance [6, 7]. Casting procedures are greatly favored. Kikuchi et al. reported that $\mathrm{Ti}-\mathrm{Cu}$ alloys may present very high mechanical strength associated with good formability [6]. The $\mathrm{Ti}-\mathrm{Cu}$ system presents an eutectoid transformation with $7.1 \% \mathrm{Cu}(\mathrm{wt} \%)$ at $790{ }^{\circ} \mathrm{C}$; under these conditions, $\alpha$-Ti and $\mathrm{Ti}_{2} \mathrm{Cu}$ are formed [8].

Many studies have been also published on the corrosion behavior of CP-Ti alloy in artificial saliva, Ringer and Hanks' solutions, and others [9-11]. The high corrosion resistance of these alloys is due to the formation

* e-mail: tlclung@mail.npust.edu.tw on its surface of an adherent and highly protective oxide film, mainly formed of $\mathrm{TiO}_{2}$ [12]. In addition, the microstructure of metallic alloys plays an important role in the mechanical properties and corrosion behavior of as-cast components [13-15].

The aim of this study was to evaluate the general electrochemical corrosion resistance of $\mathrm{Ti} 7-\mathrm{Cu}$ alloy samples obtained by casting and heat treatment. Potentiodynamic anodic polarization techniques was investigated in 0.9 wt $\% \mathrm{NaCl}$ solution at $25^{\circ} \mathrm{C}$.

\section{Experimental procedure}

Commercially pure metals ( $\mathrm{Ti} 99.8$ wt\% and $\mathrm{Cu}$ 99.99 wt\%) were used to prepare the Ti7-Cu alloy (wt\%), which is a nearly eutectoid alloy, respectively, according to the $\mathrm{Ti}-\mathrm{Cu}$ equilibrium phase diagram [8]. An as-cast $\mathrm{Ti}-7 \mathrm{Cu}$ sample was prepared by arc-melting its constituent using a current of $300 \mathrm{~A}$ on a water-cooled copper hearth under a pure Ar gas atmosphere. The as-cast $\mathrm{Ti}-7 \mathrm{Cu}$ alloy was repetitively melted and solidified with turning of the solidified ingots so as to obtain a completely alloyed state. Heat treated samples cut from the ingot were homogenized at $950^{\circ} \mathrm{C}$ for $2 \mathrm{~h}$ and then quenched in water. Hardness measurements, phase identification, and microstructure and corrosion analyses were then carried out on the as-cast and heat treated samples. Measurements were made at a minimum of five points on each specimen and averaged. X-ray diffraction (XRD, D $/ \max 2500 \mathrm{~V} / \mathrm{PC}$ ) analysis was performed to determine the phase composition of the specimens. All specimens were ground with silicon carbide papers up to 2000 mesh, polished, and etched to reveal the microstructure (Keller's etchant, $1 \mathrm{~mL}$ of $\mathrm{HF}, 2.5 \mathrm{~mL}$ of $\mathrm{HNO}_{3}$, 
$1.5 \mathrm{~mL}$ of $\mathrm{HCl}$ and $95 \mathrm{~mL}$ of $\mathrm{H}_{2} \mathrm{O}$ ). The microstructure of the alloys was examined by optical microscopy (OM) and scanning electron microscopy (SEM).

Potentiodynamic polarization were carried out in $0.9 \mathrm{wt} \% \mathrm{NaCl}$ solutions. A saturated calomel reference electrode (SCE) and a platinum $(\mathrm{Pt})$ counter-electrode were used. Prior to testing, the specimens were ground with 1200 grit $\mathrm{SiC}$ paper and cleaned in acetone for $2 \mathrm{~min}$. These tests were conducted by stepping the potential, using a scan rate of $1 \mathrm{mV} / \mathrm{s}$ from $-0.800 /+2000 \mathrm{mV}$ (SCE).

\section{Results and discussion}

The micrographs of as-cast and heat treated $\mathrm{Ti}-7 \mathrm{Cu}$ alloy samples are shown in Figs. 1 and 2, respectively. The microstructure of a rapidly solidified $\mathrm{Ti}-7 \mathrm{Cu}$ alloy sample is depicted in the OM and SEM micrographs of Fig. 1. Figure 1a shows $\alpha^{\prime}$-martensite plates of different sizes, which propagate within the pre-existing $\beta$-grains. Figure $1 \mathrm{~b}$ shows the same microstructure in a high magnification back-scattered electrons (BSE) image. It is found that the martensite structure was combined with basket-weave structure of acicular $\alpha$-Ti (dark colour) and $\mathrm{Ti}_{2} \mathrm{Cu}$ (light colour). Williams et al. [16] reported that martensite has a massive morphology in alloys containing $4 \% \mathrm{Cu}$ or less, whereas alloys containing 6 and $8 \% \mathrm{Cu}$ exhibit acicular martensite. The high cooling rate imposed on the samples promoted complete $\beta$-phase decomposition and formed acicular plates of martensite typically found in titanium alloys. Souza et al. [17] found $\alpha^{\prime}$ martensite only with cooling rates higher than $9^{\circ} \mathrm{C} / \mathrm{s}$, as the volume fractions of eutectoid and martensite depend on the magnitude of the cooling rate. In addition, they found that $\mathrm{Ti}_{2} \mathrm{Cu}$ may occur as spherical precipitates when high cooling rates are applied. The same phenomenon was also observed in the present work. Cardoso et al. [18] reported that rapidly quenched near-eutectoid $\mathrm{Ti}-\mathrm{Cu}$ alloys present $\mathrm{Ti}_{2} \mathrm{Cu}$ precipitates. Regardless of the cooling rate applied, such precipitation is unavoidable. The microstructure of the as-cast samples (in a copper mold) is in good agreement with the results from Cardoso et al.

Slow cooling of eutectoid $\mathrm{Ti}-7 \mathrm{Cu}$ alloy allowed eutectoid transformation to take place. An OM image of the slow cooled sample (Fig. 2a) shows an alternate typical basket-weave microstructure composed of lamellae of $\alpha-\mathrm{Ti}$ and $\mathrm{Ti}_{2} \mathrm{Cu}$ lamellae, as well as $\alpha$ lamellae. The detail seen in Fig. $2 \mathrm{~b}$ shows the structure under higher magnification, revealing much larger lamellar $\mathrm{Ti}_{2} \mathrm{Cu}$ phase (needles) than those found in the as-cast sample (Fig. 2b). The microstructure of the as-cast and heat treated samples (Fig. 1 and Fig. 2) suggests that faster cooling hinders the growth of the $\alpha$ phase and $\mathrm{Ti}_{2} \mathrm{Cu}$ phase, which is supported by the fact that the thickness of the plates decreases with a decreasing distance from the source of cooling.

Figure 3 shows the XRD patterns of $\mathrm{Ti}-7 \mathrm{Cu}$ alloys obtained in as-cast and heat treated samples. It is well recognized that the microstructure of $\mathrm{Ti}-\mathrm{Cu}$ binary alloys
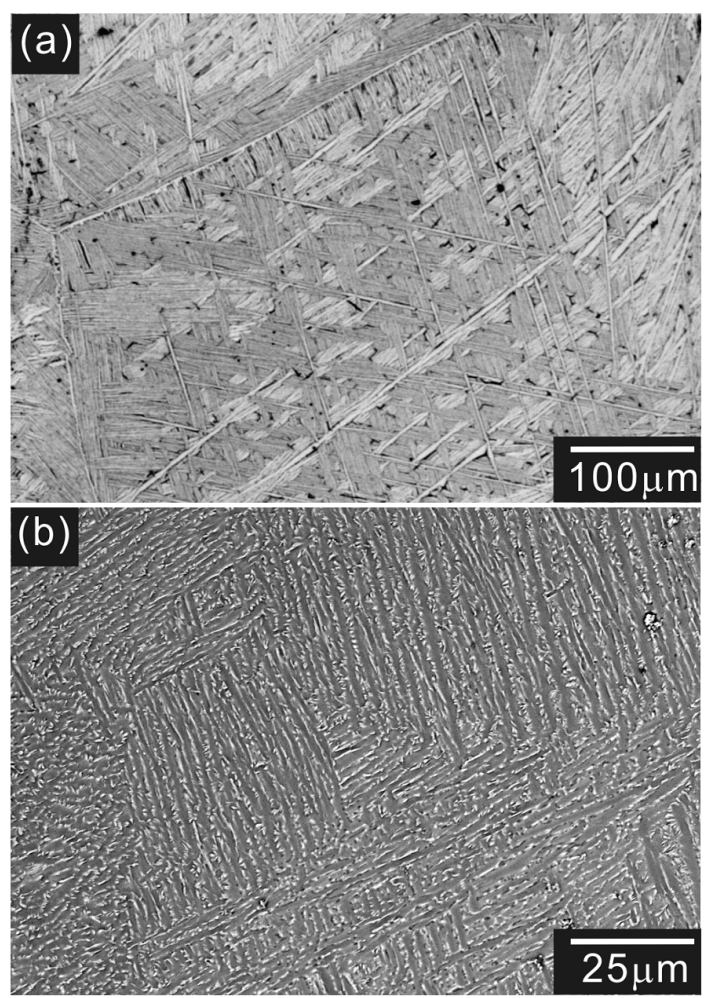

Fig. 1. Images of as-cast $\mathrm{Ti}-7 \mathrm{Cu}$ alloys: (a) $\mathrm{OM}$, (b) SEM-BSE.
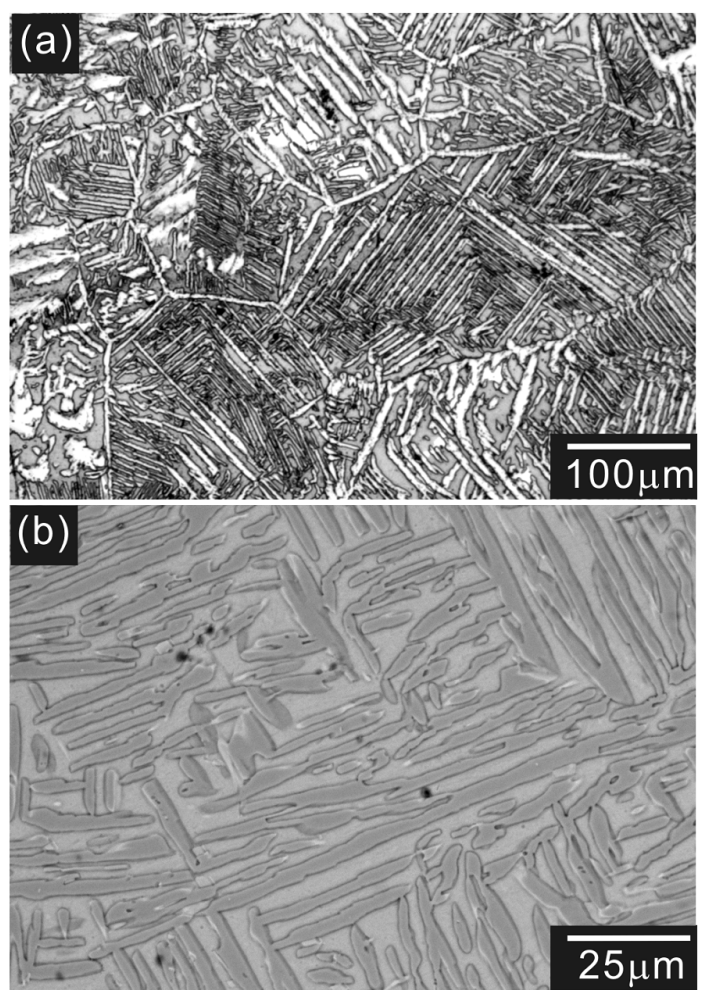

Fig. 2. Images of heat treated $\mathrm{Ti}-7 \mathrm{Cu}$ alloys: (a) $\mathrm{OM}$, (b) SEM-BSE. 


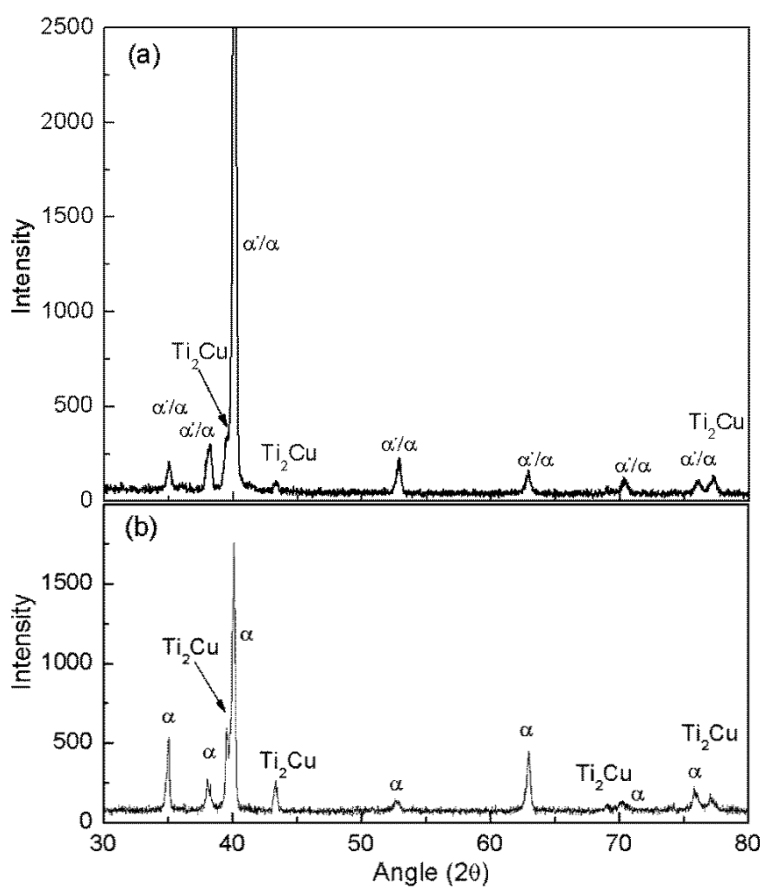

Fig. 3. X-ray diffraction patterns of: (a) as-cast sample and (b) heat treated sample.

with low $\mathrm{Cu}$ content contains $\alpha$ phase and $\mathrm{Ti}_{2} \mathrm{Cu}$ stable phases at room temperature [19]. The lattice parameters of $\alpha$ phase in a $\mathrm{Ti}-\mathrm{Cu}$ binary system were determined to have a hexagonal structure (space group $P 63 / \mathrm{mmc}$ ) with lattice parameters of $a=0.2945 \mathrm{~nm}$ and $c=0.4685 \mathrm{~nm}$. Also, the crystallographic characteristics of $\mathrm{Ti}_{2} \mathrm{Cu}$ compound are well defined in the literature as a tetragonal structure (space group $I 4 / \mathrm{mmm}$ ) with lattice parameters of $a=0.29438 \mathrm{~nm}$ and $c=1.0786 \mathrm{~nm}[20]$. It was found that the X-ray diffraction patterns of as-cast samples showed both $\alpha^{\prime}$ martensite and $\alpha$-Ti phases and slight peaks associated with the intermetallic $\mathrm{Ti}_{2} \mathrm{Cu}$, as observed in Fig. 3a. However, the X-ray diffraction patterns of the $\alpha$ phase and $\alpha^{\prime}$ martensite are remarkably similar which makes it difficult to differentiate the two phases. Additionally, the literature suggests that the lattice parameters of $\alpha$ phase in titanium alloys changes as a function of the alloying element in solution with titanium. After heat treatment, $\alpha$ peaks associated with $\mathrm{Ti}_{2} \mathrm{Cu}$ were clearly detected, and the peak of $\alpha^{\prime}$ martensite disappeared, as shown in Fig. 3b. These XRD results are in agreement with the SEM observations.

Figure 4 shows the polarization curves of the as-cast samples and those after heat treatment in a $0.9 \mathrm{wt} \%$ $\mathrm{NaCl}$ solution. From the polarization curves, the corrosion potential $\left(E_{\text {corr }}\right)$, the primary passive current $\left(I_{\mathrm{pp}}\right)$, the breakdown potential $\left(E_{\mathrm{b}}\right)$, and the dynamic corrosion current density $\left(I_{\text {corr }}\right)$ were determined and are listed in Table. The dynamic corrosion current densities $\left(I_{\text {corr }}\right)$ were obtained from the polarization curves by the Tafel plots using both cathodic and anodic branches of the po-

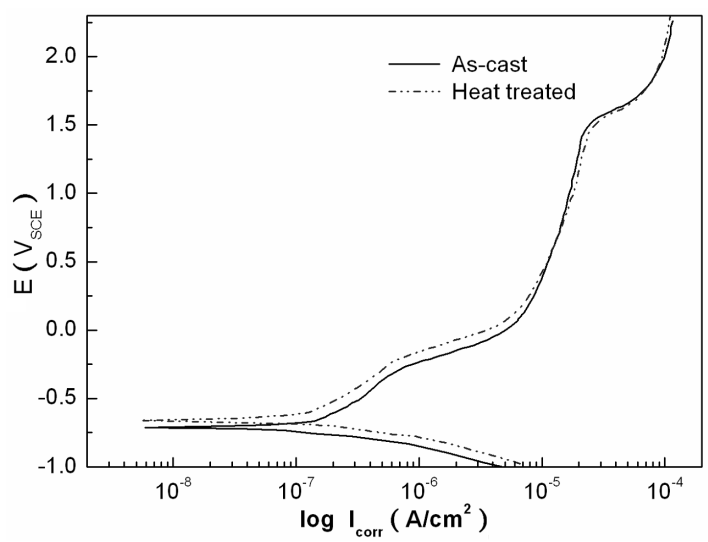

Fig. 4. Experimental potentiodynamic anodic polarization curves for $\mathrm{Ti}-7 \mathrm{Cu}$ alloys samples in a $0.9 \mathrm{wt} \%$ $\mathrm{NaCl}$ solution at $25^{\circ} \mathrm{C}$.

larization curves. The polarization curves have the same shape and are typical of passive behavior. The $E_{\text {corr }}$ of the as-cast sample is $-712 \pm 23 \mathrm{mV}_{\mathrm{SCE}}$. Nevertheless, the $E_{\text {corr }}$ of the $\mathrm{Ti}-7 \mathrm{Cu}$ alloy slightly shifted to positive values after heat treatment.

TABLE

Corrosion properties of the as-cast and heat treated $\mathrm{Ti}-7 \mathrm{Cu}$ alloys in a $0.9 \mathrm{wt} \% \mathrm{NaCl}$ solution.

\begin{tabular}{c|c|c|c|c|c}
\hline \hline Specimens & $\begin{array}{c}E_{\text {corr }} \\
{\left[\mathrm{mV}_{\mathrm{SCE}}\right]}\end{array}$ & $\begin{array}{c}E_{\mathrm{b}} \\
{\left[\mathrm{mV}_{\mathrm{SCE}}\right]}\end{array}$ & $\begin{array}{c}\Delta E \\
{[\mathrm{mV}]}\end{array}$ & $\begin{array}{c}I_{\text {corr }} \\
{\left[\mathrm{nA} / \mathrm{cm}^{2}\right]}\end{array}$ & $\begin{array}{c}I_{\mathrm{pp}} \\
{\left[\mu \mathrm{A} / \mathrm{cm}^{2}\right]}\end{array}$ \\
\hline as-cast & $-712 \pm 23$ & $1516 \pm 50$ & 2228 & $139 \pm 14$ & $7.4 \pm 0.6$ \\
heat treated & $-527 \pm 18$ & $1511 \pm 43$ & 2038 & $105 \pm 11$ & $10.2 \pm 0.9$ \\
\hline
\end{tabular}

$E_{\text {corr }}-$ corrosion potential $\left(\mathrm{mV}_{\mathrm{SCE}}\right)$,

$E_{\mathrm{b}}$ - breakdown potential $\left(\mathrm{mV}_{\mathrm{SCE}}\right)$,

$\Delta E=E_{\text {corr }}-E_{\mathrm{b}}$,

$I_{\text {corr }}$ - corrosion current density $\left(\mathrm{nA} / \mathrm{cm}^{2}\right)$,

$I_{\mathrm{pp}}$ - primary passive current.

On the other hand, the breakdown potential $\left(E_{\mathrm{b}}\right)$ of the as-cast samples became much more noble than that of heat treated samples, and the slightly large value of $\Delta E\left(=E_{\mathrm{b}}-E_{\text {corr }} ; E_{\text {corr }}=\right.$ corrosion potential $)$ for the as-cast samples reveals more stable passivation characteristics. This indicates that the pitting corrosion tendency of the as-cast sample can be alleviated due to elimination of the pitting nucleation sites in the matrix of the as-cast sample, in which a higher density of sub-micro $\mathrm{Ti}_{2} \mathrm{Cu}$ phase and the $\alpha^{\prime}$ martensite of the microstructure exist in the as-cast sample. In addition, it can be seen that the $I_{\text {corr }}$ of the as-cast specimen $\left(139 \pm 10 \mathrm{nA} / \mathrm{cm}^{2}\right)$ is slightly higher than that of the alloy after heat treatment $\left(105 \pm 11 \mathrm{nA} / \mathrm{cm}^{2}\right)$. These current densities, shown in Table, can be considered satisfactory when compared to the corresponding values obtained for CP-Ti and Ti6Al4V (of about $90 \mathrm{nA} / \mathrm{cm}^{2}$ ) [21] and quenched and heat treated Ti35Nb alloys (of about $\left.60 \mathrm{nA} / \mathrm{cm}^{2}\right)$ [22]. The different primary passive current densities $\left(I_{\mathrm{pp}}\right)$ of as-cast $\left(7.4 \pm 0.6 \mu \mathrm{A} / \mathrm{cm}^{2}\right)$ and heat treated $\mathrm{Ti}-\mathrm{Cu}$ alloys $\left(10.2 \pm 0.9 \mu \mathrm{A} / \mathrm{cm}^{2}\right)$ show similar 
values. Recently, very similar $I_{\mathrm{pp}}$ measurements were also obtained for $\mathrm{Ti}-\mathrm{Nb}-\mathrm{Zr}$ as-cast alloys [23].

\section{Conclusions}

From the present experimental investigation with as-cast and heat treated $\mathrm{Ti}-7 \mathrm{Cu}$ alloy samples, the following conclusions can be drawn:

1. The $\mathrm{Ti}_{2} \mathrm{Cu}$ phase is always present in the microstructure, regardless of the processing condition. In addition, after heat treatment, the volumetric fraction of $\mathrm{Ti}_{2} \mathrm{Cu}$ also increases.

2. The as-cast sample showed a finer $\alpha^{\prime}$ martensite structure combined with $\alpha-\mathrm{Ti}$ and $\mathrm{Ti}_{2} \mathrm{Cu}$ in the $\mathrm{Ti}-7 \mathrm{Cu}$ alloy when compared to the corresponding microstructures of the heat treated samples.

3. Both as-cast and heat treated samples present a passive behavior in this medium and high corrosion resistance. Nevertheless, their $E_{\text {corr }}$ and the stability of their passive oxide films are quite similar.

4. The experimental results of corrosion tests have indicated that only corrosion potential is significantly more noble in the heat treated samples but other characteristics are only slightly different. For example, passive current density $\left(I_{\mathrm{pp}}\right)$ is better in as cast alloy.

\section{Acknowledgments}

The authors acknowledge the financial support of this work from the National Science Council of Taiwan R.O.C. under project No. 101-2622-E-020-006-CC3.

\section{References}

[1] L.C. Tsao, H.Y. Wu, J.C. Leong, C.J. Fang, Mater. Des. 34, 179 (2012).

[2] K.L. Wapner, Clin. Orthop. Relat. Res. 271, 12 (1991).

[3] H.J. Agins, N.W. Alcock, M. Bansal, E.A. Salvati, P.D. Wilson, P.M. Pellicci, P.G. Bullough, J. Bone Joint Surg. 70A, 347 (1988).
[4] C.M. Lee, C.P. Ju, J.H. Chern Lin, J. Oral Rehabil. 29, 314 (2002).

[5] C.F. Marcinak, F.A. Young, M. Spector, J. Dent. Res. 59, 472 (1980).

[6] M. Kikuchi, Y. Takada, S. Kiyosue, M. Yoda, M. Woldu, Z. Cai, O. Okuno, T. Okabe, Dent. Mater. 19, 174 (2003)

[7] M. Taira, J.B. Moser, E.H. Greener, Dent. Mater. 5 , 45 (1989).

[8] J.L. Murray, Phase Diagrams of Binary Titanium Alloys, ASM International, Metals Park, Ohio, $\mathrm{OH}$ 1987.

[9] J. Pan, D. Thierry, C. Leygraf, Electrochim. Acta 41 , 1143 (1996).

[10] N. Ibris, J.C. Mirza-Rosca, J. Electroanalyt. Chem. 526, 53 (2002).

[11] A.K. Shukla, R. Balasubramaniam, S. Bhargava, In termetallics. 13, 631 (2005).

[12] R.W. Schutz, Handbook, Corrosion Materials, ASM International, Materials Park (OH) 2005, p. 252.

[13] W.R. Osorio, J.E. Spinelli, I.L. Ferreira, A. Garcia, Electrochim. Acta 52, 3265 (2007).

[14] W.R. Osorio, J.E. Spinelli, N. Cheung, A. Garcia, Mater. Sci. Eng. A 420, 179 (2006).

[15] D.Q. Martins, W.R. Osorio, M.E.P. Souza, R. Caram, A. Garcia, Electrochim. Acta 53, 2809 (2008).

[16] J.C. Williams, R. Taggart, D.H. Polonis, Metall Trans B 1, 2265 (1970).

[17] S.A. Souza, C.R.M. Afonso, P.L. Ferrandini, A.A. Coelho, R. Caram, Mater. Sci. Eng. A 29, 1023 (2009).

[18] F.F. Cardoso, A. Cremasco, R.J. Contieri, E.S.N. Lopes, C.R.M. Afonso, R. Caram, Mater. Des. 32, 4608 (2011)

[19] Z. Hu, Y. Zhan, J. She, G. Zhang, D. Peng, J. Alloys Comp. 485, 261 (2009).

[20] T.I. Bratanich, V.V. Skorokhod, O.V. Kucheryavyi, L.I. Kopylova, N.A. Krapivka, Powder Metall. Met Ceram. 49, 220 (2010)

[21] Z. Cai, T. Shafer, I. Watanabe, M.E. Nunn, T. Okabe, Biomaterials 24, 213 (2003).

[22] A. Cremasco, W.R. Osorio, C.M.A. Freire, A. Garcia, R. Caram, Electrochim. Acta 53, 4867 (2008).

[23] D.Q. Martins, W.R. Osorio, M.E.P. Souza, R. Caram, A. Garcia, Electrochim. Acta 53, 2809 (2008). 